\title{
Association of Cocaine- and Amphetamine-Regulated Transcript- Immunoreactive Elements with Thyrotropin-Releasing Hormone- Synthesizing Neurons in the Hypothalamic Paraventricular Nucleus and Its Role in the Regulation of the Hypothalamic-Pituitary-Thyroid Axis during Fasting
}

\author{
Csaba Fekete,, ${ }^{1,2}$ Emese Mihály, ${ }^{1}$ Lu-Guang Luo, ${ }^{3}$ Joseph Kelly, ${ }^{1}$ Jes Thorn Clausen, ${ }^{4}$ QuanFu Mao, ${ }^{3}$ \\ William M. Rand, ${ }^{5}$ Larry Gene Moss, ${ }^{1}$ Michael Kuhar, ${ }^{7}$ Charles H. Emerson, ${ }^{8}$ Ivor M. D. Jackson, ${ }^{3}$ and \\ Ronald M. Lechan 1,6

\begin{abstract}
${ }_{1}^{1}$ Tupper Research Institute and Department of Medicine, Division of Endocrinology, Diabetes, Metabolism and Molecular Medicine, New England Medical Center, Boston, Massachusetts 02111, 2Department of Neurobiology, Institute of Experimental Medicine, Hungarian Academy of Sciences, Budapest, Hungary 1083, ${ }^{3}$ Division of Endocrinology, Rhode Island Hospital and Brown University, Providence, Rhode Island 02903, ${ }^{4}$ Novo Nordisk A/S, Department of Assay and Cell Technology, Novo Alle, DK-2880 Bagsvaerd, Denmark, Departments of ${ }^{5}$ Community Health and 6 Neuroscience, Tufts University School of Medicine, Boston, Massachusetts 02111, 7Yerkes Regional Primate Center, Emory University, Atlanta, Georgia 30329, and ${ }^{8}$ Department of Medicine, Division of Endocrinology, University of Massachusetts Medical School, Worcester, Massachusetts 01655
\end{abstract}

\begin{abstract}
Because cocaine- and amphetamine-regulated transcript (CART) coexists with $\alpha$-melanocyte stimulating hormone $(\alpha-\mathrm{MSH})$ in the arcuate nucleus neurons and we have recently demonstrated that $\alpha-\mathrm{MSH}$ innervates TRH-synthesizing neurons in the hypothalamic paraventricular nucleus (PVN), we raised the possibility that CART may also be contained in fibers that innervate hypophysiotropic thyrotropin-releasing hormone $(\mathrm{TRH})$ neurons and modulate TRH gene expression. Triple-labeling fluorescent in situ hybridization and immunofluorescence were performed to reveal the morphological relationships between pro-TRH mRNAcontaining neurons and CART- and $\alpha$-MSH-immunoreactive (IR) axons. CART-IR axons densely innervated the majority of proTRH mRNA-containing neurons in all parvocellular subdivisions of the PVN and established asymmetric synaptic specializations with pro-TRH neurons. However, whereas all $\alpha$-MSH-IR axons in the PVN contained CART-IR, only a portion of CART-IR axons in contact with pro-TRH neurons were immunoreactive for $\alpha-\mathrm{MSH}$.
\end{abstract}

In the medial and periventricular parvocellular subdivisions of the PVN, CART was co-contained in $\sim 80 \%$ of pro-TRH neuronal perikarya, whereas colocalization with pro- $\mathrm{TRH}$ was found in $<10 \%$ of the anterior parvocellular subdivision neurons. In addition, $>80 \%$ of TRH/CART neurons in the periventricular and medial parvocellular subdivisions accumulated Fluoro-Gold after systemic administration, suggesting that CART may serve as a marker for hypophysiotropic TRH neurons. CART prevented fasting-induced suppression of pro-TRH in the PVN when administered intracerebroventricularly and increased the content of $\mathrm{TRH}$ in hypothalamic cell cultures. These studies establish an anatomical association between CART and pro-TRH-producing neurons in the PVN and demonstrate that CART has a stimulatory effect on hypophysiotropic $\mathrm{TRH}$ neurons by increasing pro$\mathrm{TRH}$ gene expression and the biosynthesis of $\mathrm{TRH}$.

Key words: thyrotropin-releasing hormone; thyroid axis; CART; $\alpha$-MSH; fasting; leptin
Neurons synthesizing thyrotropin-releasing hormone (TRH) in the medial and periventricular parvocellular subdivisions of the hypothalamic paraventricular nucleus (PVN) comprise the final common locus in the hypothalamus that integrates central and peripheral influences to mediate thyroid stimulating hormone (TSH) secretion from the anterior pituitary gland (Toni and Lechan, 1993). This includes a negative feedback control system that inversely relates TRH gene expression in the PVN to circulating levels of thyroid hormone (Koller et al., 1987; Segerson et al., 1987; Kakucska et al., 1992). Under certain circumstances, however, regulation of the central thyroid control system is altered in a way that may improve survival of the animal (Rondeel et al., 1992; van Haasteren et al., 1995; Legradi et al., 1997a). Thus, during fasting, when reduction of thyroid hor-

\footnotetext{
Received Aug. 29, 2000; revised Aug. 29, 2000; accepted Oct. 2, 2000.

This work was supported by National Institutes of Health Grants DK-37021 and DA-10732. We greatly appreciate the efforts of Birgitte S. Wulff of Novo Nordisk in facilitating the successful completion of this study, and the expert technical assistance of Scott Stone.

Correspondence should be addressed to Dr. Ronald M. Lechan, Professor of Medicine, Division of Endocrinology, Box 268, New England Medical Center, 750 Washington Street, Boston, MA 02111. E-mail: RLECHAN@LIFESPAN.ORG. Copyright (C) 2000 Society for Neuroscience 0270-6474/00/209224-11\$15.00/0
}

mone levels would reduce caloric expenditure, the hypothalamicpituitary-thyroid (HPT) axis becomes more sensitive to feedback inhibition by thyroid hormone and is characterized by a decrease in hypophysiotropic TRH, although circulating levels of thyroid hormone are low (Rondeel et al., 1992; van Haasteren et al., 1995; Legradi et al., 1997a).

Recent studies from our laboratory have demonstrated that the effect of leptin to restore fasting-induced inhibition of TRH gene expression in hypophysiotropic TRH neurons is mediated by the arcuate nucleus, presumably through an arcuato-paraventricular pathway that contains neuropeptide Y (NPY)-, agouti-related protein (AGRP)-, and $\alpha$-melanocyte stimulating hormone ( $\alpha$-MSH) (Legradi and Lechan, 1998, 1999; Legradi et al., 1998; Fekete et al., 2000). Each of these substances has been identified in axon terminals that establish synaptic contacts with hypophysiotropic TRH neurons (Legradi and Lechan, 1998, 1999; Fekete et al., 2000). Because the ultrastructural morphology of NPY- and AGRPcontaining synapses on TRH neurons suggests an inhibitory nature of these terminals, the activation of NPY/AGRP-containing afferents to hypophysiotropic TRH neurons during fasting may contribute to the decreased biosynthesis of TRH (Legradi and Lechan, 1998, 1999). Conversely, $\alpha$-MSH, which is antagonized by AGRP at 
melanocortin receptors (Rossi et al., 1998), is capable of restoring TRH mRNA content in the PVN to normal levels when infused intracerebroventricularly to fasted animals, suggesting that $\alpha$-MSH may stimulate the biosynthesis of TRH (Fekete et al., 2000).

Another protein of arcuate nucleus origin, cocaine- and amphetamine-regulated transcript (CART), has also been implicated in the regulation of feeding behavior (Kristensen et al., 1998; Lambert et al., 1998; Thim et al., 1998; Kuhar and Dall Vechia, 1999). CART has been identified in $\alpha$-MSH-producing neurons in the arcuate nucleus (Elias et al., 1998a), and similar to $\alpha-\mathrm{MSH}$, it inhibits feeding and antagonizes the orexigenic effect of NPY when injected intracerebroventricularly (Fan et al., 1997; Brown et al., 1998; Kristensen et al., 1998; Lambert et al., 1998; Murphy et al., 1998). Furthermore, CART mRNA is decreased in the leptindeficient ob/ob mice, suggesting that CART and $\alpha$-MSH are similarly regulated by leptin and may mediate similar responses (Kristensen et al., 1998; Ahima et al., 1999). Because we have demonstrated that hypophysiotropic TRH-producing neurons receive synaptic contacts from arcuate nucleus neurons producing $\alpha$-MSH (Fekete et al., 2000), we raised the possibility that CART may also be involved in the regulation of the hypothalamic-pituitary-thyroid axis. Thus, we conducted a series of neuroanatomical studies to establish the relationship between CART- and TRHimmunoreactive (IR) elements in the PVN and determined whether CART has an effect on TRH gene expression during fasting and on the biosynthesis of TRH in cell culture.

\section{MATERIALS AND METHODS}

\section{Animals and animal preparation}

Animals. Experiments were performed on adult male Sprague Dawley rats (Taconic Farms, Germantown, NY) that weighed 280-300 gm for the morphological studies and 210-230 gm for the CART infusion studies. The animals were housed individually in cages under standard environmental conditions (light between 6 A.M. and 6 P.M., temperature $22^{\circ} \mathrm{C}$, rat chow and water ad libitum). All experimental protocols were reviewed and approved by the Animal Welfare Committee at the New England Medical Center and Tufts University School of Medicine.

Animal preparation for morphological studies. Animals were divided into three groups. (1) In the first group $(n=3)$, animals were untreated to study the CART- and $\alpha$-MSH innervation of pro-TRH mRNA-containing neurons in the PVN. (2) In the second group $(n=6)$, animals were anesthetized with sodium pentobarbital $[50 \mathrm{mg} / \mathrm{kg}$ body weight (BW), i.p.] and stereotaxically injected intracerebroventricularly with $60-100 \mu \mathrm{g}$ colchicine in $6 \mu \mathrm{l} 0.9 \%$ saline $20 \mathrm{hr}$ before perfusion fixation of the brain, to study the ultrastructure of the CART-IR innervation of pro-TRH-IR neurons in the PVN, colocalization of pro-TRH mRNA and CART-IR in the hypothalamus, and colocalization of CART and $\alpha-\mathrm{MSH}$ in the arcuate nucleus and nucleus of solitary tract (NTS). (3) In the third group $(n=3)$, animals were injected intraperitoneally with the retrogradely transported marker substance, Fluoro-Gold $(15 \mathrm{mg} / \mathrm{kg} \mathrm{BW}$ in $1 \mathrm{ml} 0.9 \%$ saline) (Merchenthaler and Liposits, 1994), and $5 \mathrm{~d}$ later, they were treated with $100 \mu \mathrm{g}$ colchicine as described above to allow identification of TRH CART neurons that send axon terminals to the external zone of the median eminence (hypophysiotropic neurons). Because the median eminence lies outside the blood-brain barrier, axons that terminate in the external zone would be expected to concentrate Fluoro-Gold that is circulating in the blood stream, and then be transported retrogradely to their cells of origin (Merchenthaler and Liposits, 1994).

Animal preparation for CART infusion. The rats were implanted with a 22 gauge stainless steel guide cannula (Plastics One, Roanoke, VA) into the lateral cerebral ventricle under stereotaxic control (coordinates from Bregma: anteroposterior -0.8 ; lateral 1.2; dorsoventral 3.2) through a burr hole in the skull. The cannula was secured to the skull with three stainless steel screws and dental cement and temporarily occluded with a dummy cannula. Bacitracin ointment was applied daily to the interface of the cement and the skin. Animals were weighed daily, and any animal showing signs of illness or weight loss after the third postoperative day was removed from the study and euthanized. One week after intracerebroventricular cannulation, the animals were divided into three groups. The first group $(n=4)$ had free access to food and was injected intracerebroventricularly with $6 \mu \mathrm{l}$ artificial CSF containing (in $\mathrm{mM}$ ): $140 \mathrm{NaCl}, 3.35 \mathrm{KCl}, 1.15 \mathrm{MgCl}_{2}, 1.26$ $\mathrm{Ca} \mathrm{Cl}, 1.2 \mathrm{Na}_{2} \mathrm{HPO}_{4}, 0.3 \mathrm{NaH}_{2} \mathrm{PO}_{4}$, and $0.1 \% \mathrm{BSA}, \mathrm{pH} 7.4$, containing $0.1 \%$ bovine serum albumin every 6 hr for the duration of the experiment. The second $(n=4)$ and third $(n=8)$ groups were fasted for $64 \mathrm{hr}$ beginning at 4 P.M. on the first day and ended between 9 A.M. and 12 P.M. on the fourth day, injected intracerebroventricularly with $6 \mu \mathrm{l}$ artificial CSF or $0.5 \mu \mathrm{g}$ CART (Phoenix Pharmaceutical, Belmont, CA) in $6 \mu \mathrm{l}$ artificial CSF, respectively, every $6 \mathrm{hr}$. All intracerebroventricular injections were made in freely moving animals through a 28 gauge needle that extended $1 \mathrm{~mm}$ below the guide cannula, connected by polyethylene tubing to a $25 \mu \mathrm{l}$ Hamilton syringe, and infused over a period of $5 \mathrm{~min}$ by an inf usion pump (Bee Electronic Minipump, BAS, West Lafayette, IN). At completion of the experiment, the animals were anesthetized with sodium pentobarbital, blood was taken from the inferior vena cava for measurement of serum T4 and TSH, and the animals were perfused immediately with fixative as described below. Blood was collected into polypropylene tubes and centrifuged for $15 \mathrm{~min}$ at $4000 \mathrm{rpm}$, and the plasma was stored at $-80^{\circ} \mathrm{C}$ until assayed. Animals with cannulas outside the lateral ventricle as detected by light microscopic examination of the sectioned tissue (one animal from the $0.5 \mu \mathrm{g}$ CART group) were excluded from study.

\section{Tissue preparation}

Tissue preparation for in situ hybridization. Under sodium pentobarbital anesthesia $(50 \mathrm{mg} / \mathrm{kg} \mathrm{BW}$, i.p.), animals were perfused by intracardiac perfusion with $20 \mathrm{ml} 0.01 \mathrm{M}$ PBS, pH 7.4, containing 15,000 U/1 heparin sulfate followed by $150 \mathrm{ml} 4 \%$ paraformaldehyde in PBS. The brains were removed and post-fixed by immersion in the same fixative for $2 \mathrm{hr}$ at room temperature. Tissue blocks containing the hypothalamus were cryoprotected in $20 \%$ sucrose in PBS at $4^{\circ} \mathrm{C}$ overnight, then frozen on dry ice. For non-isotopic in situ hybridization, serial $20-\mu \mathrm{m}$-thick coronal sections through the rostrocaudal extent of the PVN were cut on a cryostat (Reichert-Jung 2800 Frigocut-E), collected in freezing solution (30\% ethylene glycol; $25 \%$ glycerol; $0.05 \mathrm{M}$ phosphate buffer), and stored at $-20^{\circ} \mathrm{C}$ until used. For isotopic in situ hybridization, serial $18-\mu \mathrm{m}$-thick coronal sections through the rostrocaudal extent of the PVN and the arcuate nucleus were cut on a cryostat and adhered to Superfrost/Plus glass slides (Fisher Scientific, Pittsburgh, PA) to obtain four sets of slides, each set containing every fourth section through the PVN. The tissue sections were desiccated overnight at $42^{\circ} \mathrm{C}$ and stored at $-80^{\circ} \mathrm{C}$ until prepared for in situ hybridization histochemistry.

Tissue preparation for immunofluorescence. Colchicine-treated animals were deeply anesthetized with sodium pentobarbital and perfused transcardially with $20 \mathrm{ml} 0.01 \mathrm{M} \mathrm{PBS}, \mathrm{pH} 7.4$, containing 15,000 U/1 heparin sulfate, $150 \mathrm{ml}$ of $2 \%$ paraformaldehyde $/ 4 \%$ acrolein in $0.01 \mathrm{~m}$ phosphate buffer (PB), $\mathrm{pH} 7.4$, followed by $30 \mathrm{ml}$ of $2 \%$ paraformaldehyde in the same buffer. The brains were removed and stored in PBS. For light microscopy, the brains were cryoprotected in $30 \%$ sucrose in PBS at $4^{\circ} \mathrm{C}$ overnight, then frozen on dry ice. Serial $25-\mu \mathrm{m}$-thick coronal sections through the PVN, arcuate nucleus, or brainstem were cut on a cryostat and collected in PBS. The sections were treated with $1 \%$ sodium borohydride in distilled water for $30 \mathrm{~min}$ and with $0.5 \%$ Triton $\mathrm{X}-100 / 05 \% \mathrm{H}_{2} \mathrm{O}_{2}$ in PBS for $15 \mathrm{~min}$. To reduce nonspecific antibody binding, the sections were treated with $2.5 \%$ normal horse serum in PBS for $20 \mathrm{~min}$.

Because paraformaldehyde is the suggested fixative for Fluoro-Gold, the Fluoro-Gold-injected animals were anesthetized with sodium pentobarbital and perfused transcardially with $20 \mathrm{ml} 0.1 \mathrm{M}$ PBS, pH 7.4, containing $15,000 \mathrm{U} / 1$ heparin sulfate followed by $150 \mathrm{ml}$ of $4 \%$ paraformaldehyde in $0.01 \mathrm{M}$ PBS, $\mathrm{pH}$ 7.4. The tissues were then processed for immunofluorescence as described above.

Tissue preparation for electron microscopic immunohistochemistry. Colchicine-treated animals were perfused with the same fixative as described above for immunofluorescence. The brains were removed and stored in PBS overnight at $4^{\circ} \mathrm{C}$. Serial $25-\mu \mathrm{m}$-thick coronal sections through the rostrocaudal extent of the PVN were cut on a Vibratome, collected in PBS, and stored in freezing solution at $-20^{\circ} \mathrm{C}$ until used. Then, the sections were treated with $1 \%$ sodium borohydride in $0.1 \mathrm{M}$ PB for 30 min, followed by $0.5 \% \mathrm{H}_{2} \mathrm{O}_{2}$ in PBS for $15 \mathrm{~min}$. The sections were cryoprotected in $15 \%$ sucrose in PBS for 15 min at room temperature and in $30 \%$ sucrose in $\mathrm{PBS}$ overnight at $4^{\circ} \mathrm{C}$ and quickly frozen on liquid nitrogen to improve antibody penetration of the tissue. To reduce the nonspecific antibody binding, the sections were treated with $2.5 \%$ normal horse serum in PBS for $20 \mathrm{~min}$.

\section{Immunofluorescence}

Triple-labeling fluorescence in situ hybridization/immunofluorescence of the $C A R T$ - and $\alpha$-MSH-IR innervation to pro-TRH RNA-containing neurons in the $P V N$. Because in preliminary experiments colchicine treatment was necessary to detect TRH-containing neurons by immunofluorescence, but markedly decreased the number of CART-IR axons in the PVN, CARTand $\alpha$-MSH-containing axons were detected by immunocytochemistry and pro-TRH-synthesizing neurons by in situ hybridization histochemistry in noncolchicine-treated animals. Specifically, serial sections through the hypothalamus were washed in a twofold concentration of standard sodium citrate ( $2 \times$ SSC), acetylated with $0.25 \%$ acetic anhydride in $0.9 \%$ triethanolamine for $20 \mathrm{~min}$, and then treated in graded solutions of acetone (50, $70,90,100 \%)$, chloroform, and a descending series of acetone $(100,90,70$ $50 \%$ ) for $5 \mathrm{~min}$ each. After further washes in $2 \times \mathrm{SSC}, 3 \times \mathrm{SSC}$, and $4 \times$ $\mathrm{SSC}$ for $5 \mathrm{~min}$ each, the sections were hybridized with the digoxigeninlabeled cRNA probe for pro-TRH.

The digoxigenin-labeled antisense pro-TRH cRNA probe was synthesized using a 1241 base pair cDNA template corresponding to the coding sequence of pro-TRH mRNA and portions of its $5^{\prime}$ and $3^{\prime}$ untranslated sequences (Dyess et al., 1988; Kakucska et al., 1992). Briefly, $1 \mu \mathrm{g}$ of linearized plasmid was incubated with $0.5 \mu \mathrm{l} 10 \mathrm{~mm}$ digoxigenin-11-UTP (Boehringer Mannheim, Indianapolis, IN) in the presence of excess nucleotides and SP6 polymerase for $1 \mathrm{hr}$ at $37^{\circ} \mathrm{C}$. The nucleotide mixture was 
then digested with DNase and precipitated with $0.1 \mathrm{vol}$ of $4.0 \mathrm{M} \mathrm{NaCl}$ and 3 vol of $100 \%$ ethanol. The probe was resuspended in $100 \mu \mathrm{l} 0.1 \%$ SDS solution and stored at $80^{\circ} \mathrm{C}$ (Peterson et al., 1994). The hybridization was performed in $200 \mu \mathrm{l}$ polypropylene tubes in a hybridization buffer $(50 \%$ formamide, $2 \times$ SSC, $10 \%$ dextran sulfate, $0.5 \%$ SDS, $250 \mu \mathrm{g} / \mathrm{ml}$ denatured salmon sperm DNA) containing the digoxigenin-labeled probe, diluted at 1:50 for $16 \mathrm{hr}$ at $56^{\circ} \mathrm{C}$. The slides were washed in $1 \times \mathrm{SSC}$ for $15 \mathrm{~min}$ and then treated with RNase $(25 \mu \mathrm{g} / \mathrm{ml})$ for $1 \mathrm{hr}$ at $37^{\circ} \mathrm{C}$. After additional washes in $0.1 \times \mathrm{SSC}$ (four times for $15 \mathrm{~min}$ each) at $65^{\circ} \mathrm{C}$, sections were washed in PBS, treated with the mixture of $0.5 \%$ Triton X-100 and $0.5 \%$ $\mathrm{H}_{2} \mathrm{O}_{2}$ for $15 \mathrm{~min}$, and then with $2 \%$ BSA in PBS for 20 min to reduce the nonspecific antibody binding. The sections were incubated with a mixture of sheep anti-digoxigenin-peroxidase Fab fragments (1:100; Boehringer Mannheim), rabbit anti-CART antiserum diluted at 1:2000 (Koylu et al., 1997), and sheep anti- $\alpha$-MSH antiserum diluted at 1:5000 (Elias et al., $1998 \mathrm{~b}$ ) in $1 \% \mathrm{BSA}$ in PBS for $2 \mathrm{~d}$ at $4^{\circ} \mathrm{C}$. The sections were rinsed in PBS and then incubated in $0.1 \%$ biotinylated tyramide and $0.01 \% \mathrm{H}_{2} \mathrm{O}_{2}$ in PBS for $10 \mathrm{~min}$ to intensify the hybridization signal (Adams, 1992). After further washes, the sections were incubated in a mixture of 7-amino-4-methylcoumarin-3-acetic acid (AMCA) Avidin D (1:250; Vector Labs, Burlingame, CA), FITC-conjugated donkey anti-rabbit IgG (1:40; Jackson Immunoresearch, West Grove, PA), and Texas Redconjugated donkey anti-rabbit IgG (1:40: Jackson Immunoresearch), mounted on uncoated slides, and coverslipped with Vectashield mounting medium (Vector).

Double-labeing immunofluorescence of CART- and $\alpha$-MSH-IR in arcuate nucleus and nucleus of the solitary tract neurons. Tissue sections through the arcuate nucleus were incubated in a mixture of sheep anti- $\alpha$-MSH antiserum (1:5000) and rabbit antiserum to CART $(1: 2000)$ as described above but diluted in antibody diluent $(2.5 \%$ normal horse serum, $0.2 \%$ Kodak Photo-Flo, and $0.2 \%$ sodium azide in $0.01 \mathrm{M} \mathrm{PBS}, \mathrm{pH} 7.4$ ). After rinses in PBS, the sections were incubated in Texas Red-conjugated donkey antisheep IgG (1:40; Jackson Immunoresearch) and FITC-conjugated donkey anti-rabbit $\operatorname{IgG}(1: 40$; Jackson Immunoresearch) for $2 \mathrm{hr}$ at room temperature.

To determine whether CART- and $\alpha$-MSH-IR colocalize in neurons in the nucleus of the solitary tract, coronal tissue sections through the medulla were incubated in a mixture of the sheep anti- $\alpha$-MSH antiserum $(1: 30,000)$ and rabbit antiserum to CART $(1: 2000)$ in antibody diluent. After incubation in biotinylated donkey anti-sheep IgG for $2 \mathrm{hr}$ (1:500; Jackson Immunoresearch) followed by the avidin-biotin-peroxidase complex (ABC Elite, 1:100; Vector) in PBS for $2 \mathrm{hr}$ at room temperature, the $\alpha$-MSH signal was intensified using $0.1 \%$ biotinylated tyramid and $0.01 \%$ $\mathrm{H}_{2} \mathrm{O}_{2}$ in PBS (Adams, 1992) for $10 \mathrm{~min}$. The sections were then incubated in the mixture of Texas Red Avidin DCS (1:250; Vector) and FITCconjugated donkey anti-rabbit IgG (1:40; Jackson Immunoresearch).

Double-labeling fluorescence in situ hybridization and immunofluorescence

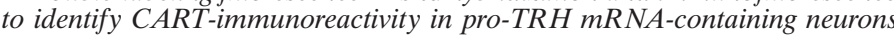
in the PVN. Sections of colchicine-treated animals through the hypothalamus were hybridized with the digoxigenin-labeled cRNA probe for proTRH as described above. After the washing steps, the sections were incubated in a mixture of sheep anti-digoxigenin-peroxidase Fab fragments (1:100; Boehringer Mannheim) and rabbit anti-CART antiserum diluted at 1:2000 (Koylu et al., 1997) in 1\% BSA in PBS for $2 \mathrm{~d}$ at $4^{\circ} \mathrm{C}$ and prepared for fluorescence microscopy as described above.

Identification of axons and hypophysiotropic neurons in the PVN that co-contain CART and TRH. Sections through the PVN were incubated in a mixture of a rabbit antiserum against prepro-TRH 178-199 (1:3000) and murine monoclonal CART antibody, Ca\&-1F4.D4 $(1.67 \mu \mathrm{g} / \mathrm{ml})$ (Vrang et al., 1999) for $2 \mathrm{~d}$ at $4^{\circ} \mathrm{C}$. The sections were rinsed in PBS and treated with FITC-conjugated donkey anti-rabbit IgG (1:40; Jackson Immunoresearch) and rhodamine-conjugated horse anti-mouse $\operatorname{IgG}$ for $2 \mathrm{hr}$ at room temperature.

To identify hypophysiotropic neurons that co-contain CART and TRH, the above protocol was applied to sections through the hypothalamus from the Fluoro-Gold-injected animals. The autofluorescence of Fluoro-Gold was used to detect the retrogradely transported tracer.

\section{Electron microscopic immunohistochemistry}

Sections processed for electron microscopy were incubated in the murine monoclonal CART antibody, Ca\&-1F4.D4 $(1.67 \mu \mathrm{g} / \mathrm{ml})$, and diluted in antibody diluent for $4 \mathrm{~d}$ at $4^{\circ} \mathrm{C}$, followed by biotinylated horse anti-mouse IgG (1:500; Vector Labs) for $12 \mathrm{hr}$ at $4^{\circ} \mathrm{C}$ and the ABC Elite complex (1:100) for $3 \mathrm{hr}$ at room temperature. Immunoreactivity was detected in $0.025 \% \mathrm{DAB} / 0.0036 \% \mathrm{H}_{2} \mathrm{O}_{2}$ in $0.05 \mathrm{M}$ Tris Buffer, $\mathrm{pH}$ 7.6. The sections were then placed into rabbit anti-prepro-TRH 178-199 (1:8000), as a marker of TRH neurons (Fekete et al., 2000), for $2 \mathrm{~d}$ at $4^{\circ} \mathrm{C}$, and after they were rinsed in PBS and $0.1 \%$ cold water fish gelatin (Electron Microscopy Sciences, Fort Washington, PA) in PBS, they were incubated in goat anti-rabbit IgG conjugated with $0.8 \mathrm{~nm}$ colloidal gold (Electron Microscopy Sciences) diluted at 1:100 in PBS containing $0.1 \%$ cold water fish gelatin. The sections were washed in the same diluent and PBS, followed by a 10 min treatment in $1.25 \%$ glutaraldehyde in PBS. After they were rinsed in $0.2 \mathrm{M}$ sodium citrate, $\mathrm{pH} 7.5$, the gold particles were silver-intensified with IntenSE Kit (Amersham, Arlington Heights, IL) (Branchereau et al., 1995). Sections were treated with $1 \%$ osmium tetroxide in $0.1 \mathrm{M}$ PB for 30 min, dehydrated in an ascending series of ethanol followed by propylene oxide, flat-embedded in Durcupan ACM epoxy resin (Fluka, Ronkonkoma, NY) on liquid release agent (Electron Microscopy Sciences) coated slides, and polymerized at $56^{\circ} \mathrm{C}$ for $2 \mathrm{~d}$. Ultrathin $50-60 \mathrm{~nm}$ sections were cut with an MRC MT6000 ultramicrotome (MRC, Tucson, AZ), collected onto Formvar-coated single slot grids, contrasted with $2 \%$ uranyl acetate, and examined with a Phillips CM-10 electron microscope.

\section{Isotopic in situ hybridization histochemistry.}

Every fourth section of the PVN from the CART-infused and control animals was hybridized with a 1241 base pair single-stranded $\left[{ }^{35}\right.$ S]UTPlabeled cRNA probe for pro-TRH as described previously (Dyess et al., 1988; Kakucska et al., 1992). The hybridization was performed under plastic coverslips in hybridization buffer containing $6 \times 10^{5} \mathrm{cpm}$ of radiolabeled probe for $16 \mathrm{hr}$ at $56^{\circ} \mathrm{C}$. Slides were dipped into Kodak NTB2 autoradiography emulsion (Eastman Kodak, Rochester, NY), and the autoradiograms were developed after $2 \mathrm{~d}$ of exposure at $4^{\circ} \mathrm{C}$. The specificity of hybridization was confirmed using sense probes, which resulted in the absence of specific hybridization in the PVN.

\section{Image analysis}

Subdivisions (anterior and medial parvocellular) of the PVN were defined according to Swanson and Kuypers (1980).

Triple-labeled sections for the CART- and $\alpha$-MSH-IR innervation of pro-TRH mRNA-containing neurons were imaged with a Zeiss 410 confocal microscope using the following laser excitation lines: $364 \mathrm{~nm}$ for AMCA, $488 \mathrm{~nm}$ for FITC, and $568 \mathrm{~nm}$ for Texas Red. Dichroic/emission filters for detection were $400 \mathrm{~nm} \mathrm{LP} / 415-455 \mathrm{~nm}$ AMCA, $500 \mathrm{~nm} \mathrm{LP} / 515$ $565 \mathrm{~nm}$ for FITC, and $575 \mathrm{~nm} \mathrm{LP} / 590 \mathrm{LP}$ for Texas Red. These filter combinations resulted in negligible cross-talk between individual fluorochrome signals.

Other fluorescent preparations were analyzed under a Zeiss Axioskop 2 epifluorescent microscope using the following filter sets: AMCA-excitation 320-400 nm, bandpass $400 \mathrm{~nm}$, emission 430-490 nm; FITCexcitation $460-500 \mathrm{~nm}$, bandpass $505 \mathrm{~nm}$, emission 510-560 nm; Texas Red/rhodamine - excitation 540-590 nm, bandpass $595 \mathrm{~nm}$, emission 600 $660 \mathrm{~nm}$; Immuno-Gold 340-380 excitation nm, bandpass $400 \mathrm{~nm}$, emission $>500 \mathrm{~nm}$. Images were captured with a Spot digital camera (Diagnostic Instrument, Sterling Heights, MI), the same field double- or triple-exposed while switching the filter sets for each fluorochrome, and superimposed using Adobe Photoshop 5.0 and a Macintosh G4 computer to create composite images for analysis.

Autoradiograms for pro-TRH in situ hybridization were visualized under dark-field illumination using a COHU 4910 video camera (COHU, San Diego, CA) and analyzed with a Macintosh G4 computer using Scion Image. Background density points were removed by thresholding the image, and integrated density values (density $\times$ area) of hybridized neurons in the same region of each side of the PVN were measured in six consecutive sections for each animal and summed. Nonlinearity of radioactivity in the emulsion was evaluated by comparing density values with a calibration curve created from autoradiograms of known dilutions of the radiolabeled probes immobilized on glass slides in $2 \%$ gelatin fixed with $4 \%$ formaldehyde and exposed and developed simultaneously with the in situ hybridization autoradiograms.

\section{Antibody characterization}

Specificity of the anti-CART (Koylu et al., 1997; Vrang et al., 1999) and anti- $\alpha$-MSH (Elias et al., 1998b; Fekete et al., 2000; Mihaly et al., 2000) antisera for immunohistochemistry have been reported previously. Antipro-TRH 178-199 was a gift of Dr. E. Redei (Northwestern University, Chicago, IL) and shown by Nillni et al. (2000) to recognize a $2.6 \mathrm{kDa}$ peptide characteristic of prepro-TRH $178-199$ by electrophoretic separation of immunoprecipitated radiolabeled peptides from primary cultures of rat hypothalamic neurons and AtT-20 tumor cells expressing transfected prepro-TRH cDNA, and from extracts of the hypothalamic PVN and median eminence by SDS-PAGE and radioimmunoassay (RIA). In addition, no specific staining could be detected by omission of each primary or secondary antiserum.

\section{Hormone measurements}

Plasma T4 and TSH concentrations were measured by RIA. Materials for the TSH RIA were provided by the National Institute of Diabetes and Digestive and Kidney Diseases (NIDDK) National Hormone and Pituitary Program (Baltimore, MD) using NIDDK rat TSH RP-2 as the standard. Plasma T4 levels were measured with a specific RIA using antiserum from Ventrex (Portland, ME) and $\left[{ }^{125} \mathrm{I}\right]$-labeled T4 obtained from New England Nuclear (Boston, MA). The details of the assay have been reported previously (Castro et al., 1986). The Cobra 500 program was used for data reduction and calculation of the RIA results.

\section{Primary neuronal cultures}

The diencephalon was dissected from day 17 rat fetuses and dispersed enzymatically with $1 \%$ neutral protease (Sigma, St. Louis, MO) and in monolayers grown in wells precoated with poly-D-lysine $(20 \mu \mathrm{g} / \mathrm{ml}$, Sigma). The plating density was $10^{6}$ cells per milliliter. The cells were maintained in bicarbonate buffered DMEM supplemented with $10 \%$ fetal calf serum, 

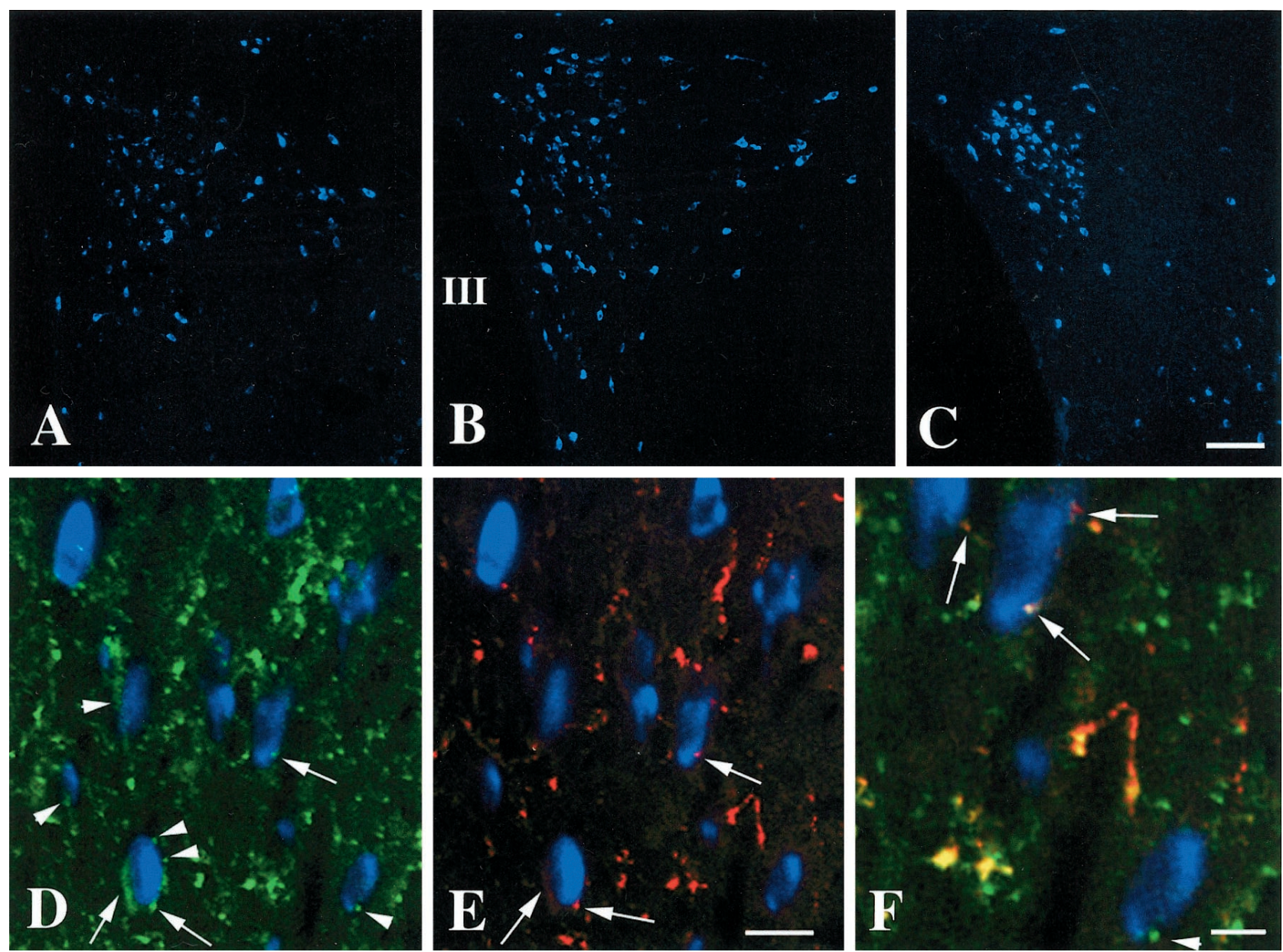

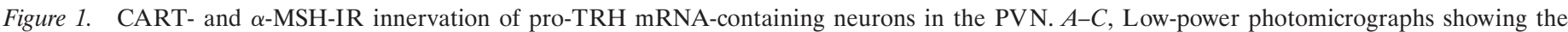

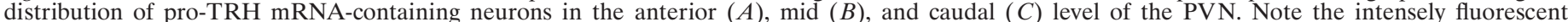

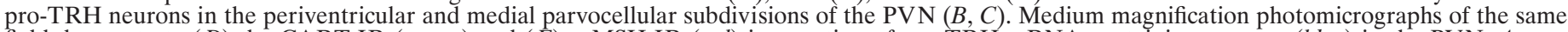

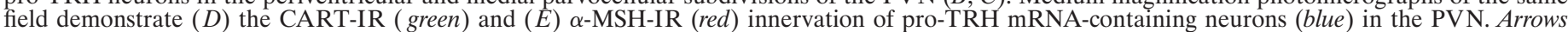

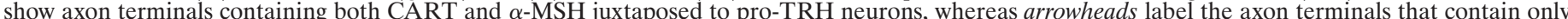

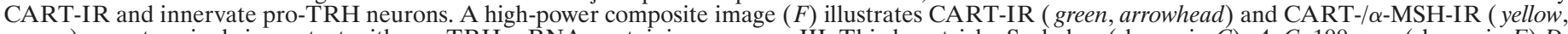

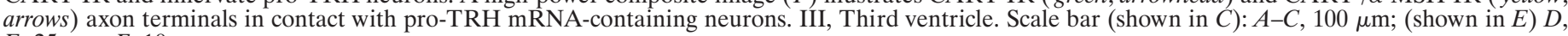
$E, 25 \mu \mathrm{m} ; F, 10 \mu \mathrm{m}$.

at $37^{\circ} \mathrm{C}, 5 \% \mathrm{CO}_{2}$ and $95 \%$ humidity (Bruhn et al., 1996). After preincubation for $7 \mathrm{~d}$, the neurons were exposed to CART for $7 \mathrm{hr}$ at doses ranging from $10^{-10}$ to $10^{-7} \mathrm{M}(n=6$ for each dose $)$. The cells were extracted in $1 \mathrm{~N}$ acetic acid, boiled for $10 \mathrm{~min}$, homogenized, and centrifuged at $2000 \times$ g. RIA for TRH was performed as described previously (Jackson, 1989).

\section{Statistical analysis}

All data were analyzed by one-way ANOVA using contrasts to test specific hypotheses. For testing the relationships between fed, fasting, and fasting plus CART groups (density values representing pro-TRH mRNA in the in situ hybridization autoradiograms, and T4/TSH values in plasma by RIA), two orthogonal contrasts were used, the first comparing the fed with the fasted animals, and the second between fasted animals and the fasted animals treated with CART. For testing for a linear trend of the TRH content in hypothalamic neuronal cultures and TRH secreted into the medium, a linear contrast was used. In each case, the analysis of contrast was preceded by Levene's test to establish that the group variances could be considered equal. All data are presented as means and SEs of the mean. Data were entered into and analyzed using SPSS version 9 (SPSS, Chicago, IL).

\section{RESULTS}

\section{Distribution of pro-TRH mRNA-containing neurons in the PVN by fluorescent in situ hybridization histochemistry}

With fluorescent detection of the hybridization signal and intensification with biotinylated tyramide, the blue fluorescence of AMCA was observed to fill the perikarya of pro-TRH-containing neurons and the base of their first order dendrites (Fig. $1 A-C$ ), allowing cells in all locations previously reported using a $\left[{ }^{35} \mathrm{~S}\right]-$ labeled pro-TRH probe (Lechan and Segerson, 1989) to be easily seen. In particular, the anterior, medial, and periventricular parvocellular subdivisions of PVN contained fluorescently labeled pro-TRH mRNA-synthesizing neurons (Fig. $1 A-C$ ). The highest concentration of fluorescent pro-TRH mRNA neurons was observed in the periventricular and medial parvocellular subdivisions of the PVN (Fig. $1 B, C$ ), particularly in the most caudal portion of the medial parvocellular subdivision (Fig. $1 C$ ). The anterior parvocellular subdivision also contained pro-TRH-synthesizing neurons, but these neurons were loosely dispersed and showed a less intense fluorescent signal (Fig. $1 A$ ). The lateral and ventral parvocellular subdivisions of the PVN contained only few labeled cells.

Outside the PVN in the same tissue sections, hybridization signal was readily apparent in the dorsomedial nucleus, lateral hypothalamus, perifornical area, and reticular nucleus of thalamus.

\section{CART- and $\alpha$-MSH-IR innervation of pro-TRH mRNA- containing neurons in the PVN}

A high density of CART-IR fibers was found throughout the parvocellular subdivisions of the PVN and appeared to contact nearly all pro-TRH mRNA-containing neurons in each of the anterior, medial, and periventricular parvocellular subdivisions, sometimes encircling the pro-TRH-synthesizing neuronal perikarya (Fig. 1D). However, although all $\alpha$-MSH-IR fibers in the PVN contained CART-IR (Fig. $1 D-F$ ), only a portion of CART-IR axons in contact with pro-TRH neurons were immunoreactive for 

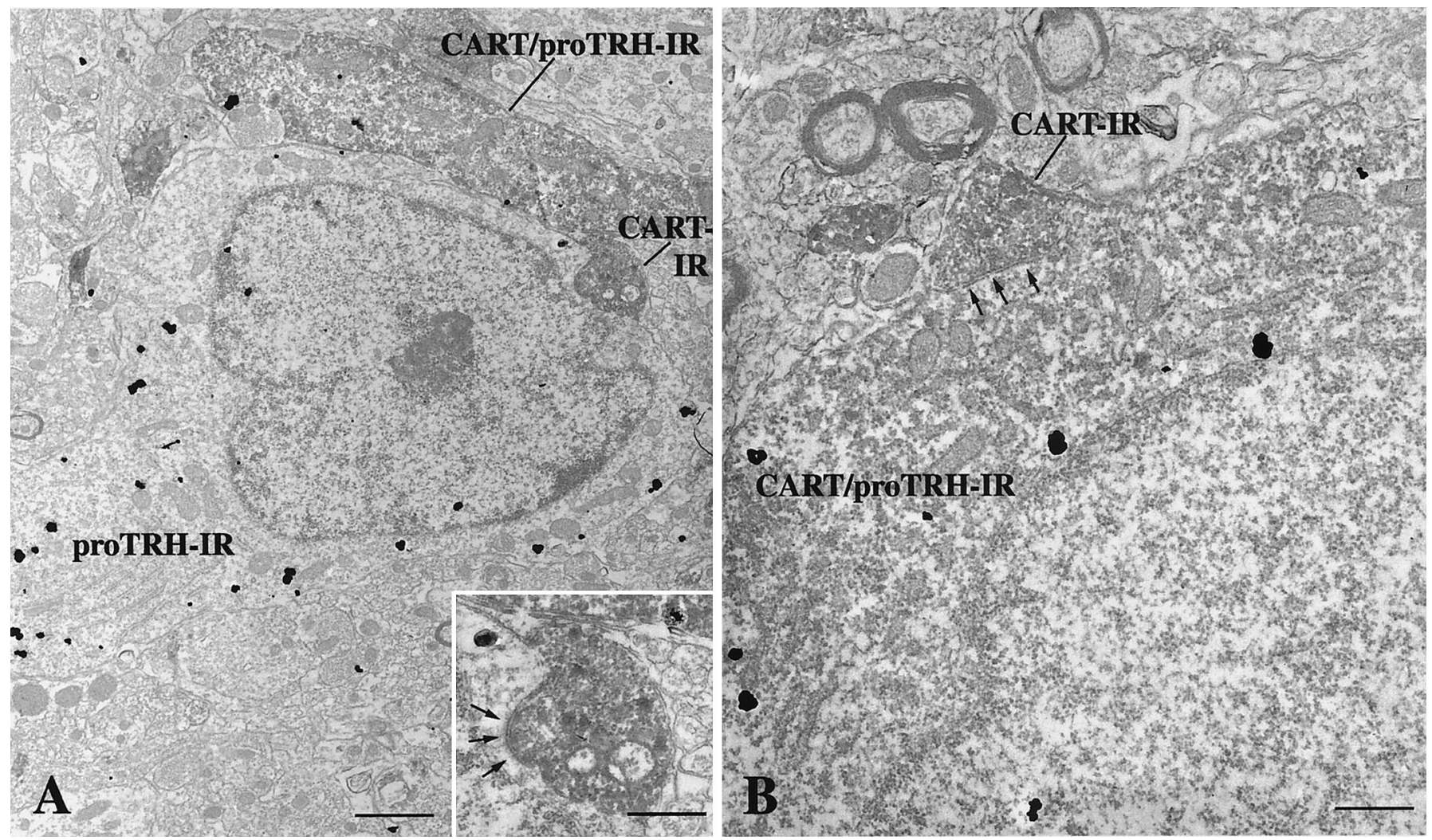

Figure 2. Electron micrographs showing synaptic associations (arrows) between CART-containing axon terminals and neuronal perikarya containing pro-TRH-IR $(A)$ or pro-TRH- and CART-IR $(B)$ in the medial parvocellular subdivision of the PVN. The pro-TRH-IR is labeled with highly electron-dense silver granules, whereas the CART-IR is recognized by the presence of the electron-dense DAB. $A$, Medium-power magnification view of a CART-IR asymmetric synapse on the perikarya of a pro-TRH neuron, shown in greater detail in the inset. A dendrite co-containing CART and pro-TRH is also apparent in the image. $B$, High-power magnification of an axosomatic synapse between a CART-IR axon terminal and a neuronal perikarya co-containing CART and pro-TRH. Scale bars: $A, 1 \mu \mathrm{m} ; B$ and inset, $0.4 \mu \mathrm{m}$.

$\alpha$-MSH (Fig. $1 D-F$ ). Axon varicosities containing both $\alpha$-MSH and CART appeared larger than axons containing only CART-IR and were found in contact with pro-TRH mRNA-containing neurons primarily in the anterior and periventricular parvocellular subdivisions of the PVN. Most of the pro-TRH neurons in contact with $\mathrm{CART} / \alpha-\mathrm{MSH}$-containing fibers were also contacted by the separate population of smaller CART-IR axon varicosities that did not cocontain $\alpha$-MSH.

\section{Ultrastructural analysis of CART-IR innervation of pro- TRH-IR neurons in the PVN}

In the parvocellular subdivisions of the PVN, highly electron-dense silver-intensified gold particles labeling pro-TRH-IR were found in small and medium-sized neurons and dendrites (Fig. 2). The majority of pro-TRH-IR neurons contained both heavy metal particles and electron-dense DAB precipitation, the latter labeling CART-IR. CART-IR was also found in terminals containing numerous small, clear vesicles and some dense-core vesicles. Tracing the CART-IR terminals juxtaposed to pro-TRH-IR neurons through a series of ultrathin sections revealed that these terminals established asymmetric-type synaptic specializations with both pro-TRH (Fig. $2 A$ ) and pro-TRH/CART neurons (Fig. $2 B$ ).

\section{Double-labeling immunofluorescence of CART and $\alpha$ - MSH in the arcuate nucleus and nucleus of the solitary tract}

In the arcuate nucleus, most $\alpha$-MSH-IR neurons were found to contain CART-IR in their perikarya. Only rare, singly labeled $\alpha$-MSH- or CART-containing neurons were observed, located mainly in the medial portion of the nucleus (Fig. $3 A, B$ ).

In the nucleus of the solitary tract, the only other region in the brain where proopiomelanocortin is synthesized (Joseph et al., 1983), medium-sized multipolar $\alpha$-MSH-IR neurons were found exclusively in the commissural part of the nucleus. In contrast, CART-IR neurons were located mainly in the rostral part of the nucleus of the solitary tract. The commissural part of the nucleus contained a dense network of CART-IR fibers but few CART-IR perikarya. No double-labeled neurons containing both CART- and $\alpha$-MSH were found in any subdivision of the nucleus of the solitary tract (Fig. 3C,D).

\section{Colocalization of CART-IR and pro-TRH mRNA- containing neurons in the PVN}

In sections of colchicine-treated animals, numerous CART-IR neurons could be visualized by immunofluorescence in the periventricular, medial and ventral parvocellular subdivisions of the PVN, whereas only scattered CART-IR neurons were found in the anterior parvocellular subdivision (Fig. $4 A-C$ ). The TRH hybridization signal was not affected by the colchicine treatment. In the anterior parvocellular subdivision, only $9.5 \pm 2.1 \%$ of TRH mRNA-containing neurons showed CART-IR (Fig. 4A). Most of these doubly labeled neurons were medial, near the periventricular parvocellular subdivision, and contained an intense TRH hybridization signal. In contrast to the anterior parvocellular subdivision, the periventricular and medial parvocellular subdivisions of the PVN contained numerous doubly labeled neurons: $79.9 \pm 3.3 \%$ and $80.2 \pm 1.3 \%$, respectively. The caudal part of the medial parvocellular subdivision showed a particularly high colocalization of CART-IR in TRH-producing neurons, where nearly all proTRH neurons contained CART-IR (Fig. $4 C$ ). Most of the singlelabeled pro-TRH-containing neurons were located laterally in the most anterior part of these subdivisions. Numerous single-labeled CART-IR neurons were found in the periventricular and ventral parvocellular subdivisions.

None of the pro-TRH mRNA-containing neurons in the lateral 


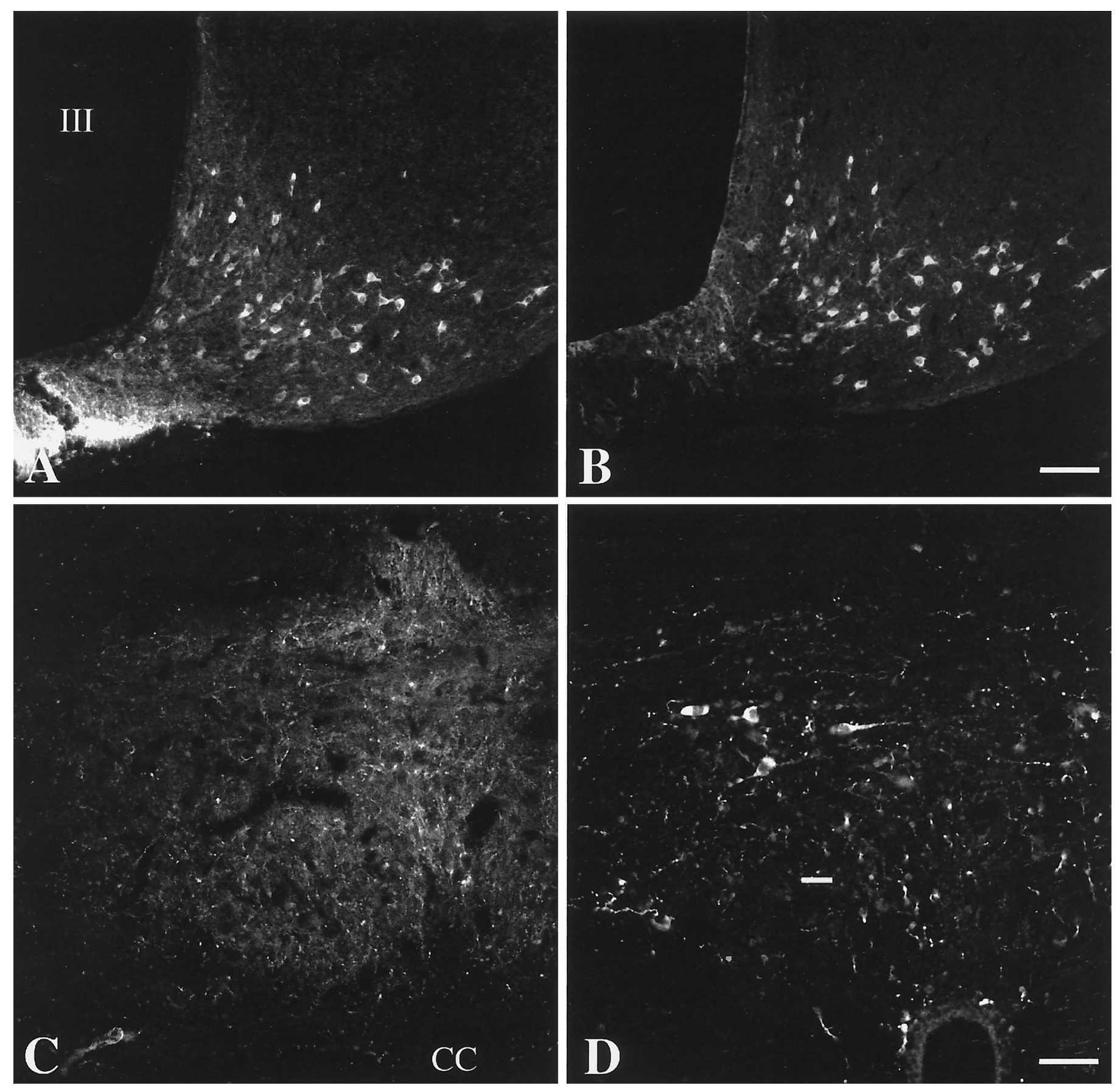

Figure 3. Double immunolabeling for CART- and $\alpha$-MSH-IR in the arcuate nucleus and commissural part of the nucleus of the solitary tract (NTS). $A$ and $B$, and $C$ and $D$ are the same tissue section. In the arcuate nucleus $(A, B)$, most of the CART-IR neurons $(A)$ co-contain $\alpha$-MSH-IR $(B)$ in its perikarya. Only occasional single-labeled neurons are visible in the nucleus. In contrast, no colocalization between CART $(C)$ and $\alpha$-MSH $(D)$ is seen in photomicrographs taken from the identical field of the commissural part of NTS. III, Third ventricle; $C C$, central canal. Scale bars (shown in $B$ ): $A, B$, $100 \mu \mathrm{m}$; (shown in $D$ ): $C, D, 50 \mu \mathrm{m}$.

hypothalamus, perifornical area, hypothalamic dorsomedial nucleus, and reticular nucleus of thalamus contained CART-IR.

\section{Identification of hypophysiotropic neurons that co- contain CART- and pro-TRH-IR in the PVN and} distribution of their axon terminals in the hypothalamus

Intensely fluorescent, Fluoro-Gold-containing neurons were found in both the magnocellular and parvocellular subdivisions of the PVN, with the exception of the anterior parvocellular subdivision, where only a few Fluoro-Gold-containing neurons were observed (Fig. $4 E$ ). In triple-labeled tissue sections, the majority of TRH-IR neurons in the periventricular $(88.2 \pm 3.8 \%)$ and medial $(80.2 \pm$ $1.4 \%$ ) parvocellular subdivisions of the PVN showed CART-IR and accumulated Fluoro-Gold (Fig. $4 F, G$ ). In contrast, only rare TRH-IR neurons were found to contain Fluoro-Gold or CART-IR in the anterior parvocellular subdivision (Fig. 4D,E). In addition, the few pro-TRH-IR neurons in the periventricular and medial parvocellular subdivisions that were not immunoreactive for CART also did not contain Fluoro-Gold.

Axon terminals co-containing pro-TRH and CART concentrated in only two regions of the brain: the median eminence (Fig. $4 H$ ) and the organum vasculosum laminae terminalis (OVLT) (Fig. 4I). In the median eminence, CART-IR fibers were observed in both the internal and external zones, but co-existed with pro$\mathrm{TRH}$ only in the external zone (Fig. $4 H$ ). In the OVLT, all 

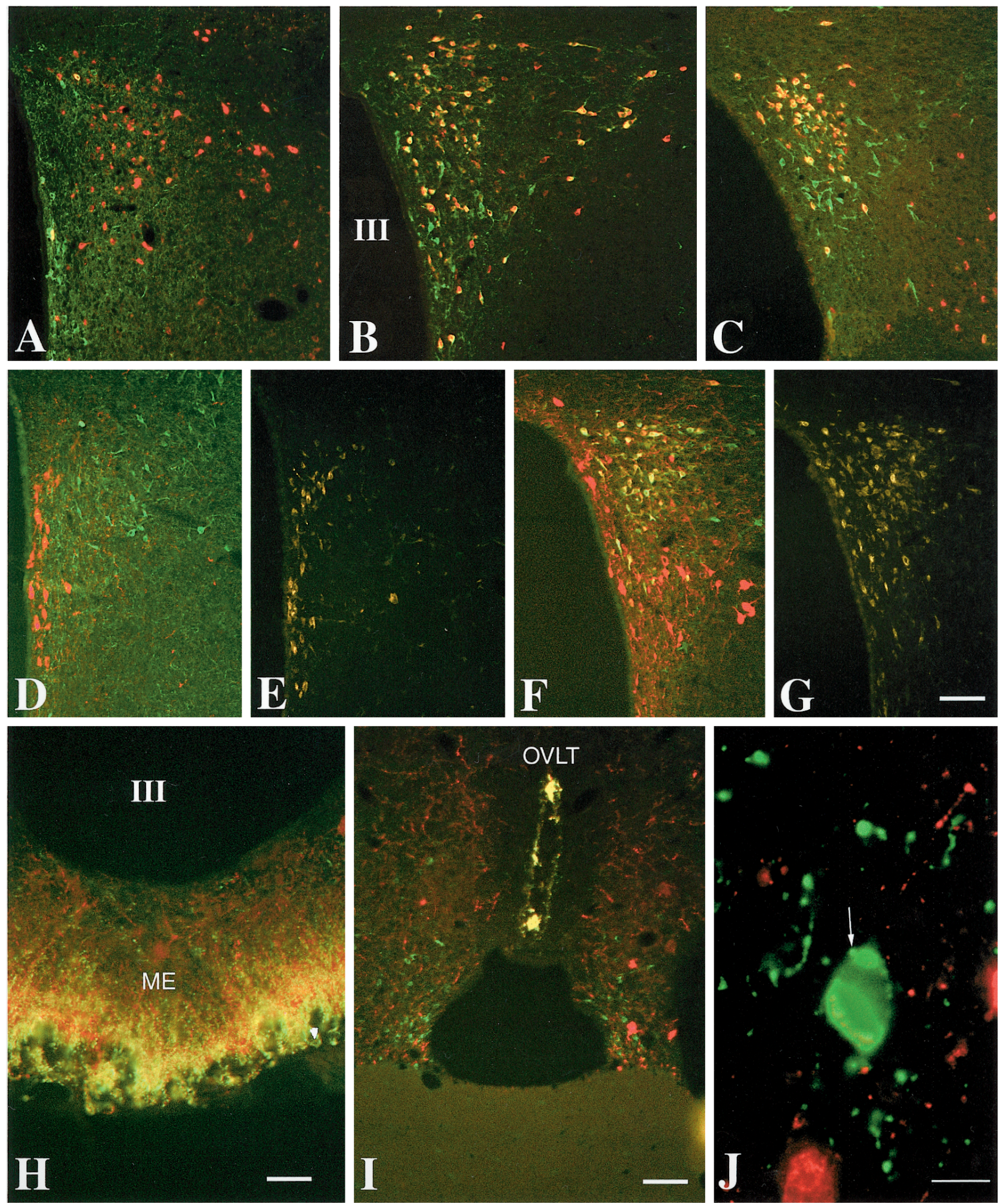

Figure 4. Colocalization of CART and pro-TRH-containing neuronal elements in the rat hypothalamus. $A-C$, Low-power micrographs show pro-TRH mRNA- (labeled with AMCA, but pseudocolored red for improved illustration of the CART/pro-TRH colocalization) and CART-containing (green) perikarya in the PVN. Neurons co-containing CART and pro-TRH appear yellow. In the anterior parvocellular subdivision $(A)$, only occasional double-labeled neurons ( yellow) can be found, whereas most of the pro-TRH mRNA-containing neurons in the periventricular and medial parvocellular subdivisions co-contain CART-IR $(B, C)$. $D$, Low-power micrographs of the anterior parvocellular subdivision of the PVN again illustrate that the majority of pro-TRH-IR neurons ( green) in the subdivision form a separate and distinct population from CART-IR neurons (red), but as seen in $E$, these singly labeled TRH neurons do not accumulate Fluoro-Gold from the blood stream. In contrast, the majority of pro-TRH-IR neurons in the periventricular and medial parvocellular subdivisions co-contain CART-IR (yellow cells in $F$ ) and accumulate Fluoro-Gold from the blood stream ( $G$ ). In the external zone of the median eminence $(M E)(H)$ and in the $O V L T(I)$, nearly all pro-TRH-IR axons co-contain CART-IR, as indicated by the yellow color in these regions resulting from color mixing (green fluorescence $=$ pro-TRH-IR; red fluorescence $=$ CART-IR). High-power photomicrograph $(J)$ shows that pro-TRH axon terminals innervating pro-TRH neurons in the PVN do not contain CART-IR. III, Third ventricle. Scale bars (shown in $G): A-G, 100 \mu \mathrm{m} ; H, 50 \mu \mathrm{m} ; I, 100 \mu \mathrm{m} ; J, 10 \mu \mathrm{m}$. 

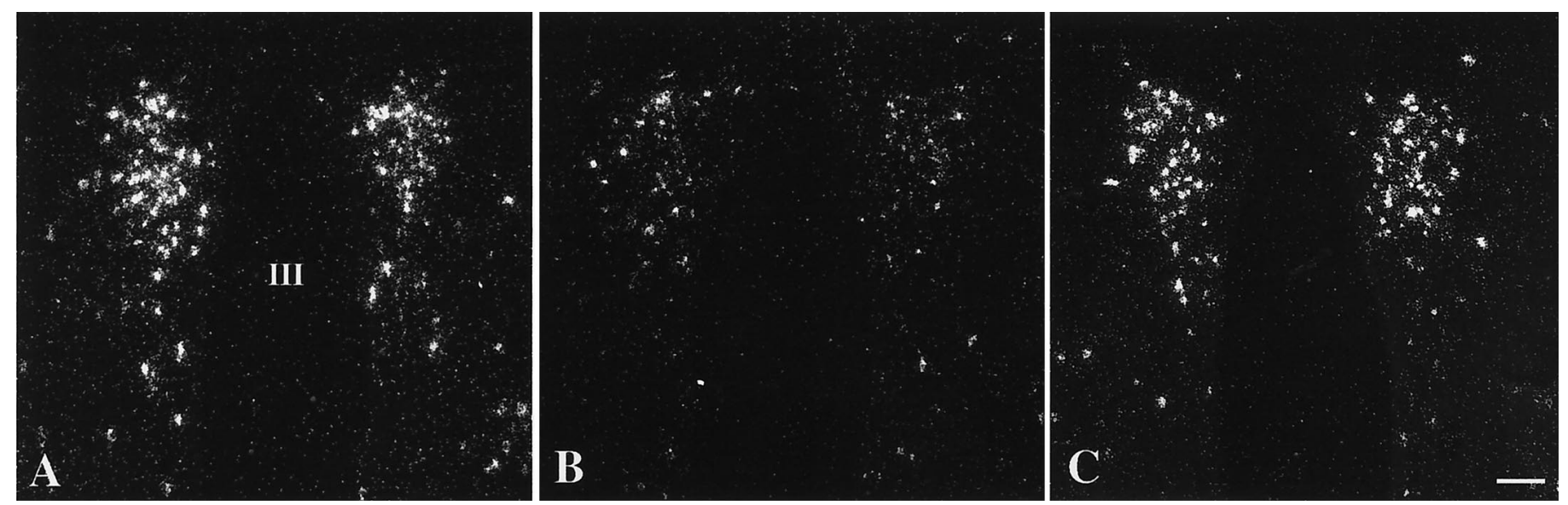

Figure 5. Dark-field illumination micrographs of pro-TRH mRNA in the medial and periventricular parvocellular subdivisions of the hypothalamic PVN in fed $(A)$ and fasted $(B)$ animals and fasted animals receiving an intracerebroventricular infusion of CART at a dose of $0.5 \mu \mathrm{g}(C)$ every $6 \mathrm{hr}$ for $64 \mathrm{hr}$. Note the reduction in the accumulation of silver grains over the PVN in fasted animals compared with the fed controls. Fasted animals receiving CART every $6 \mathrm{hr}$, however, show a marked increase in pro-TRH mRNA, similar to that of fed control animals. III, Third ventricle. Scale bar, $100 \mu \mathrm{m}$.

pro-TRH-IR fibers contained CART-IR, but the number of TRH/ CART fibers in the median eminence far exceeded that in the OVLT (Fig. 4I).

Only rare pro-TRH-IR axon terminals co-contained CART-IR in the PVN. In addition, CART-IR was not observed in pro-TRH-IR axons innervating pro-TRH neurons in the PVN (Fig. 4J).

\section{Effect of fasting and CART administration to fasting animals on body weight and behavior}

Fasted animals lost $17.4 \pm 0.8 \%$ body weight during the experiment, whereas the fed controls gained $5.6 \pm 1.3 \%$ body weight. Fasted animals receiving $0.5 \mu \mathrm{g}$ CART injection also showed significant weight reduction $(19.8 \pm 0.5 \%)$, which was not significantly different from the weight loss of the fasted control animals.

Distinct behavioral manifestations were observed immediately after the central administration of CART and persisted for $\sim 2 \mathrm{hr}$. These behaviors were characterized by quiescence and movementassociated tremor, as described earlier by Kristensen et al. (1998), but attenuated after subsequent CART injections and were no longer apparent during the final day of the experiment. However, the CART-injected animals were observed to chew the cage bedding, and this persisted over the $3 \mathrm{~d}$ of experimentation.

\section{Effect of fasting and CART administration to fasting animals on pro-TRH mRNA in the PVN}

In fed animals, neurons containing pro-TRH mRNA were readily visualized by in situ hybridization histochemistry, symmetrically distributed in the medial and periventricular parvocellular subdivisions of the PVN on either side of the third ventricle (Fig. 5A), whereas fasting caused a marked decrease in the hybridization signal over these neurons (Fig. 5B). By image analysis, density values of pro-TRH mRNA in the PVN of fasting animals was $47 \%$ of the intact animals (Fig. 6). In fasted animals receiving $0.5 \mu \mathrm{g}$ CART every $6 \mathrm{hr}$, however, the hybridization pattern appeared identical to that of the fed controls (Fig. 5C). Density values showed that the fasted animals differed from the fed animals $(4.0 \pm$ 0.6 vs $8.4 \pm 1.3 ; p=0.034)$ and the fasted animals receiving $0.5 \mu \mathrm{g}$ CART ( $4.0 \pm 0.6$ vs $7.9 \pm 1.2 ; p=0.035)$ (Fig. 6).

\section{Effect of CART on plasma levels of T4 and TSH}

Fasting resulted in a significant fall in plasma T4 values (fed vs fast, micrograms per deciliter: $4.2 \pm 0.5$ vs $1.1 \pm 0.3 ; p=0.014)$, but the administration of CART to fasting animals did not significantly increase T4 (fast vs fast $+0.5 \mu \mathrm{g}$ CART, micrograms per deciliter: $1.1 \pm 0.3$ vs $1.8 \pm 0.8 ; p=0.47)$. No significant differences in TSH were observed among the three groups (fed vs fast vs fast $+0.5 \mu \mathrm{g}$ CART, microunits per milliliter: $28.0 \pm 5.9$ vs $21.3 \pm 5.3$ vs $21.3 \pm$



Figure 6. Computerized image analysis of pro-TRH mRNA content in the PVN of fed and fasted animals and fasted animals receiving an intracerebroventricular infusion of CART at a dose of $0.5 \mu \mathrm{g}$. ${ }^{*} p<0.05$ compared with fasted animals.



Figure 7. Content of TRH in hypothalamic primary cultures $7 \mathrm{hr}$ after the addition of CART to the medium.

1.2), although the TSH level in the fasting animal was inappropriately low for the markedly reduced T4 level.

\section{Effect of CART on TRH content of hypothalamic primary cultures}

In primary cell culture, there was a significant linear relationship $(p=0.018)$ between the dose of CART and the cellular content of TRH (control vs $10^{-10}, 10^{-9}, 10^{-8}$, and $10^{-7}$ M CART, femtomoles per well: $108.1 \pm 2.2$ vs $109.86 \pm 1.25,110.61 \pm 1.35,117 \pm$ 22 and $119.2 \pm 1.9$, respectively) (Fig. 7). 


\section{DISCUSSION}

CART has recently been added to the rapidly expanding list of leptin-regulated proteins involved in the control of energy expenditure (Kristensen et al., 1998; Lambert et al., 1998). Similar to that described for $\alpha$-MSH and other agonists of the MC3/4 receptors (Fan et al., 1997; Murphy et al., 1998), CART has been shown to inhibit food intake and antagonize the orexigenic effect of NPY (Kristensen et al., 1998; Lambert et al., 1998). Conversely, immunoneutralization of CART by central administration of CART antiserum facilitates feeding (Kristensen et al., 1998; Lambert et al., 1998). Because CART has been shown to colocalize with $\alpha$-MSH in the hypothalamic arcuate nucleus (Elias et al., 1998a), and $\alpha$-MSH of arcuate nucleus origin is contained in axons that contact TRH neurons in the PVN and stimulate TRH gene expression in fasting animals (Fekete et al., 2000), we were interested in investigating whether CART is also anatomically situated to exert effects on hypophysiotropic TRH neurons and stimulate TRH gene expression in fasting animals.

In this study, we observed that TRH neurons are heavily inundated by CART-containing axon terminals in all parvocellular subdivisions of the PVN. At the ultrastructural level, CART-IR terminals formed asymmetric synaptic contacts with pro-TRH-IR neurons, suggesting an excitatory role of these terminals (Peters et al., 1991). By triple-labeling fluorescent techniques, two types of CART-containing axons were identified having morphologically distinct characteristics. The first included axons with larger varicosities, distributed mainly in the periventricular and anterior parvocellular subdivisions of PVN that contained $\alpha$-MSH-IR. This type of CART axon formed juxtapositions with the majority of TRH mRNA-containing neurons in the anterior and periventricular subdivisions. Because the only source of $\alpha-\mathrm{MSH}$ in the brain other than the hypothalamic arcuate nucleus is the nucleus tractus solitarius (NTS) (Joseph et al., 1983; Bronstein et al., 1992), and CART-IR did not colocalize with $\alpha$-MSH in NTS neurons, we presume that the origin of the CART $/ \alpha-\mathrm{MSH}$ co-containing axons that contact TRH neurons in the PVN is exclusively the arcuate nucleus.

The second type of CART-IR axons innervating pro-TRH neurons in the PVN appeared more delicate, terminated in smaller, varicosities, and did not co-contain $\alpha$-MSH. These varicosities contacted almost all TRH mRNA-containing neurons in all parvocellular subdivisions of the PVN and were more numerous than axon varicosities containing both CART and $\alpha$-MSH. Although technical causes could explain the absence of $\alpha$-MSH in these fibers, the different morphological characteristics of these terminals would indicate that they may derive from a separate population of neurons. Several possibilities should be considered. Because the PVN contains a large number of CART-IR neurons and immunohistochemical and electrophysiological studies have provided evidence for the existence of synaptic connections between neurons within the parvocellular PVN itself (Renaud, 1981; Swanson and Sawchenko, 1983), these CART-IR axon varicosities may originate locally within the PVN. Alternatively, TRH neurons in the PVN may be innervated by CART-containing axons originating from neuronal groups outside the PVN. CART is synthesized in many neuronal groups that potentially could project to the PVN, including the preoptic periventricular nucleus, lateral hypothalamus, zona incerta, NTS, and the catecholamine $\mathrm{C} 1$ area of the brainstem (Sawchenko and Swanson, 1983; Koylu et al., 1997; Koylu et al., 1998).

In addition to the CART-IR innervation of TRH neurons in the PVN, we have confirmed observations made by Broberger (1999) in the mouse that TRH neurons in the PVN of the rat co-contain CART in their perikarya. Before these reports, no peptide was known to coexist with TRH in the PVN neurons. Only occasional TRH neurons were observed to contain corticotropin-releasing hormone, neurotensin, pituitary adenylate cyclase-activating polypeptide, and enkephalin (Ceccatelli et al., 1989; Legradi et al., 1997b). In contrast to the observation by Broberger (1999), however, who found that most of the neurons that express pro-TRH
mRNA in PVN, including the anterior parvocellular subdivision, contain CART, we were only able to identify CART in $<10 \%$ of TRH neurons in the anterior parvocellular subdivision of the PVN. However, $\sim 80 \%$ of the neurons expressing pro-TRH mRNA in the medial and periventricular parvocellular subdivisions of the PVN contained CART. Because the majority of anterior parvocellular subdivision TRH neurons did not accumulate the retrogradely transported marker substance Fluoro-Gold after systemic injection, we believe that these TRH neurons are functionally distinct from those in the medial and periventricular parvocellular subdivisions and do not subserve a hypophysiotropic function. Similar conclusions have been made by Kawano et al. (1991) and Merchenthaler et al. (1994). Further evidence to support this conclusion has revealed that only the medial and periventricular parvocellular PVN neurons show enlargement of their cell cytoplasm (Nishiyama et al., 1985) and upregulation of their pro-TRH mRNA content (Kakucska et al., 1992) in response to hypothyroidism. The selectivity for the colocalization of CART in medial and periventricular parvocellular TRH neurons that accumulate Fluoro-Gold, and the presence of CART in TRH axon terminals in the median eminence, therefore, would suggest that CART may be a specific marker for hypophysiotropic TRH neurons and have an important role in the regulation of TSH synthesis in the anterior pituitary. Because a small number of TRH/CART axon terminals are present in the OVLT, which like the median eminence also lies outside the blood-brain barrier, we cannot exclude the possibility that some of the CART/TRH neurons in the PVN are not hypophysiotropic. Rather, these neurons may secrete their products into the blood vessels of the OVLT. Nevertheless, the OVLT has a vascular connection with the blood vessels of the median eminence (Ambach et al., 1976; Larsen et al., 1991), and therefore, TRH secreted into the OVLT may ultimately affect anterior pituitary TSH secretion. The additional possibility that hypophysiotropic TRH neurons in the PVN have dual projections to the median eminence and OVLT should be also considered.

Recent studies from our laboratory have demonstrated that $\alpha$-MSH-containing axons of arcuate nucleus origin establish synaptic contacts with both the soma of first order dendrites of proTRH-IR neurons in the PVN (Fekete et al., 2000), and that many of these neurons also are contacted by a separate population of axons containing the melanocortin receptor antagonist, agoutirelated protein (AGRP) (Fekete et al., 2000). We have proposed that the convergence of $\alpha$-MSH- and AGRP-containing axons on the same pro-TRH neuron provide morphological evidence to suggest an interaction between melanocortin agonist and antagonistic effects to regulate the transcription of pro-TRH mRNA (Fekete et al., 2000). Indeed, the intracerebroventricular infusion of $\alpha$-MSH to fasting animals results in a marked upregulation of pro-TRH mRNA and a rise in circulating levels of thyroid hormone (Fekete et al., 2000). Nevertheless, even doses of $\alpha$-MSH that increase pro-TRH mRNA to the level of fed animals do not completely restore circulating thyroid hormone levels to normal (Fekete et al., 2000), whereas the systemic administration of leptin to fasting animals completely restores the HPT axis to normal (Legradi et al., 1997a). Accordingly, other factors that respond to leptin administration and act in coordination with $\alpha$-MSH may be necessary to achieve the full regulatory response of leptin on the HPT axis. Given that CART colocalizes with $\alpha$-MSH in axon terminals that innervate hypophysiotropic TRH neurons, we examined the effect of CART administration on TRH gene expression in the PVN of fasted animals and TRH content in hypothalamic primary cultures.

Although fasted animals receiving only vehicle intracerebroventricularly showed a significant reduction in pro-TRH mRNA in the PVN compared with fed controls, as reported previously (Blake et al., 1991; Legradi et al., 1997a), the administration of $0.5 \mu \mathrm{g}$ CART intracerebroventricularly every $6 \mathrm{hr}$ completely reversed the effect of fasting on pro-TRH gene expression, resulting in a hybridization pattern that looked identical to that of the fed animals in all parvocellular subdivisions of the PVN, suggesting that an increase 
in the synthesis of CART in the arcuate nucleus (Elias et al., 1998a) may participate in the effect of leptin to increase pro-TRH mRNA in the PVN. The ability of both CART and $\alpha$-MSH to similarly affect pro-TRH gene expression in PV N neurons in fasting animals suggests that more than one peptide is capable of modulating hypophysiotropic TRH neurons in response to circulating levels of leptin. Alternatively, CART may potentiate the action of $\alpha-\mathrm{MSH}$ on hypophysiotropic TRH neurons, and this possibility will require further study. Along these lines, the ability of CART to increase the accumulation of TRH in hypothalamic cultures indicates that this peptide is capable of not only stimulating the transcription and translation of the $\mathrm{TRH}$ gene but also facilitating the processing of the TRH prohormone.

Despite the ability of CART to replicate the effects of leptin on TRH gene expression in hypophysiotropic neurons in fasting animals, CART did not restore circulating thyroid hormone levels to normal as previously observed after leptin administration (Legradi et al., 1997a; Ahima et al., 1999) or partially toward normal as observed after the intracerebroventricular administration of $\alpha$-MSH (Fekete et al., 2000). These data imply that CART mediates only a part of the effects of leptin on the HPT axis in fasted animals and that additional factors must also be called into play after leptin administration to generate the full biological response. One must also consider the possibility, however, that in addition to activating the TRH gene, the intracerebroventricular administration of CART could have simultaneous effects on other factors that may negatively influence the TSH response from anterior pituitary thyrotropes to TRH. These effects may be the consequence of the wide access of the CART peptide to the brain and possibly the pituitary via the CSF, as opposed to selective release to specific populations of neurons as might occur after leptin administration. As an example of potential confounding factors that could influence circulating thyroid hormone levels, the intracerebroventricular administration of CART also increases corticosterone levels, possibly through direct effects on hypophysiotropic corticotropinreleasing hormone neurons in the PVN (Vrang et al., 2000), and corticosterone is known to inhibit TSH release from the anterior pituitary (Samuels and McDaniel, 1997). In addition, CART has been identified in somatostatin-containing neurons in the hypothalamic periventricular nucleus (Vrang et al., 1999) that are known to project to the external zone of the median eminence (Liposits et al., 1993). Because somatostatin is inhibitory to the release of TSH (Hugues et al., 1986), the possibility that the intracerebroventricular administration of CART might simultaneously release somatostatin into the portal capillary plexus for conveyance to the anterior pituitary must also be considered. Finally, it is not known what action CART itself may exert directly on the anterior pituitary after release from axon terminals in the median eminence and whether these actions could ultimately inhibit TSH secretion.

We conclude that CART may have an important role in the regulation of hypophysiotropic TRH neurons by increasing proTRH gene expression and the biosynthesis of TRH. In addition, colocalization of CART and TRH primarily in hypophysiotropic neurons raises the possibility that CART may modulate the effect of TRH on TSH secretion in the anterior pituitary.

\section{REFERENCES}

Adams JC (1992) Biotin amplification of biotin and horseradish peroxidase signals in histochemical stains. J Histochem Cytochem 40:1457-1463.

Ahima RS, Kelly J, Elmquist JK, Flier JS (1999) Distinct physiologic and neuronal responses to decreased leptin and mild hyperleptinemia. Endocrinology 140:4923-4931.

Ambach G, Palkovits M, Szentagothai J (1976) Blood supply of the rat hypothalamus. IV. Retrochiasmatic area, median eminence, arcuate nucleus. Acta Morphol Acad Sci Hung 24:93-119.

Blake NG, Eckland DJ, Foster OJ, Lightman SL (1991) Inhibition of hypothalamic thyrotropin-releasing hormone messenger ribonucleic acid during food deprivation. Endocrinology 129:2714-2718.

Branchereau P, Van Bockstaele EJ, Chan J, Pickel VM (1995) Ultrastructural characterization of neurons recorded intracellularly in vivo and injected with lucifer yellow: advantages of immunogold-silver vs. immunoperoxidase labeling. Microsc Res Tech 30:427-436.

Broberger C (1999) Hypothalamic cocaine- and amphetamine-regulated transcript (CART) neurons: histochemical relationship to thyrotropinreleasing hormone, melanin-concentrating hormone, orexin/hypocretin and neuropeptide Y. Brain Res 848:101-113.

Bronstein DM, Schafer MK, Watson SJ, Akil H (1992) Evidence that beta-endorphin is synthesized in cells in the nucleus tractus solitarius: detection of POMC mRNA. Brain Res 587:269-275.

Brown KS, Gentry RM, Rowland NE (1998) Central injection in rats of alpha-melanocyte-stimulating hormone analog: effects on food intake and brain Fos. Regul Pept 78:89-94.

Bruhn TO, Rondeel JM, Bolduc TG, Luo LG, Jackson IM (1996) Activation of thyrotropin-releasing hormone gene expression in cultured fetal diencephalic neurons by differentiating agents. Endocrinology 137:572-579.

Castro MI, Alex S, Young RA, Braverman LE, Emerson CH (1986) Total and free serum thyroid hormone concentrations in fetal and adult pregnant and nonpregnant guinea pigs. Endocrinology 118:533-537.

Ceccatelli S, Eriksson M, Hokfelt T (1989) Distribution and coexistence of corticotropin-releasing factor-, neurotensin-, enkephalin-, cholecystokinin-, galanin- and vasoactive intestinal polypeptide/peptide histidine isoleucine-like peptides in the parvocellular part of the paraventricular nucleus. Neuroendocrinology 49:309-323.

Dyess EM, Segerson TP, Liposits Z, Paull WK, Kaplan MM, Wu P, Jackson IM, Lechan RM (1988) Triiodothyronine exerts direct cellspecific regulation of thyrotropin-releasing hormone gene expression in the hypothalamic paraventricular nucleus. Endocrinology 123:2291-2297.

Elias CF, Lee C, Kelly J, Aschkenasi C, Ahima RS, Couceyro PR, Kuhar MJ, Saper CB, Elmquist JK (1998a) Leptin activates hypothalamic CART neurons projecting to the spinal cord. Neuron 21:1375-1385.

Elias CF, Saper CB, Maratos-Flier E, Tritos NA, Lee C, Kelly J, Tatro JB, Hoffman GE, Ollmann MM, Barsh GS, Sakurai T, Yanagisawa M, Elmquist JK (1998b) Chemically defined projections linking the mediobasal hypothalamus and the lateral hypothalamic area. J Comp Neurol 402:442-459.

Fan W, Boston BA, Kesterson RA, Hruby VJ, Cone RD (1997) Role of melanocortinergic neurons in feeding and the agouti obesity syndrome. Nature 385:165-168.

Fekete C, Legradi G, Mihaly E, Huang QH, Tatro JB, Rand W M, Emerson $\mathrm{CH}$, Lechan RM (2000) alpha-melanocyte-stimulating hormone is contained in nerve terminals innervating thyrotropin-releasing hormonesynthesizing neurons in the hypothalamic paraventricular nucleus and prevents fasting-induced suppression of prothyrotropin-releasing hormone gene expression. J Neurosci 20:1550-1558.

Hugues JN, Enjalbert A, Moyse E, Shu C, Voirol MJ, Sebaoun J, Epelbaum J (1986) Differential effects of passive immunization with somatostatin antiserum on adenohypophysial hormone secretions in starved rats. J Endocrinol 109:169-174.

Jackson IM (1989) Controversies in TRH biosynthesis and strategies towards the identification of a TRH precursor. Ann N Y Acad Sci 553:7-13.

Joseph SA, Pilcher WH, Bennett-Clarke C (1983) Immunocytochemical localization of ACTH perikarya in nucleus tractus solitarius: evidence for a second opiocortin neuronal system. Neurosci Lett 38:221-225.

Kakucska I, Rand W, Lechan RM (1992) Thyrotropin-releasing hormone gene expression in the hypothalamic paraventricular nucleus is dependent upon feedback regulation by both triiodothyronine and thyroxine. Endocrinology 130:2845-2850.

Kawano H, Tsuruo Y, Bando H, Daikoku S (1991) Hypophysiotrophic TRH-producing neurons identified by combining immunohistochemistry for pro-TRH and retrograde tracing. J Comp Neurol 307:531-538.

Koller KJ, Wolff RS, Warden MK, Zoeller RT (1987) Thyroid hormones regulate levels of thyrotropin-releasing-hormone mRNA in the paraventricular nucleus. Proc Natl Acad Sci USA 84:7329-7333.

Koylu EO, Couceyro PR, Lambert PD, Ling NC, DeSouza EB, Kuhar MJ (1997) Immunohistochemical localization of novel CART peptides in rat hypothalamus, pituitary and adrenal gland. J Neuroendocrinol 9:823-833.

Koylu EO, Couceyro PR, Lambert PD, Kuhar MJ (1998) Cocaine- and amphetamine-regulated transcript peptide immunohistochemical localization in the rat brain. J Comp Neurol 391:115-132.

Kristensen P, Judge ME, Thim L, Ribel U, Christjansen KN, Wulff BS, Clausen JT, Jensen PB, Madsen OD, Vrang N, Larsen PJ, Hastrup S (1998) Hypothalamic CART is a new anorectic peptide regulated by leptin. Nature 393:72-76.

Kuhar MJ, Dall Vechia SE (1999) CART peptides: novel addiction- and feeding-related neuropeptides. Trends Neurosci 22:316-320.

Lambert PD, Couceyro PR, McGirr KM, Dall Vechia SE, Smith Y, Kuhar MJ (1998) CART peptides in the central control of feeding and interactions with neuropeptide Y. Synapse 29:293-298.

Larsen PJ, Moller M, Mikkelsen JD (1991) Efferent projections from the periventricular and medial parvicellular subnuclei of the hypothalamic paraventricular nucleus to circumventricular organs of the rat: a Phaseolus vulgaris-leucoagglutinin (PHA-L) tracing study. J Comp Neurol 306:462-479.

Lechan RM, Segerson TP (1989) Pro-TRH gene expression and precursor peptides in rat brain. Observations by hybridization analysis and immunocytochemistry. Ann NY Acad Sci 553:29-59.

Legradi G, Lechan RM (1998) The arcuate nucleus is the major source for neuropeptide $\mathrm{Y}$-innervation of thyrotropin-releasing hormone neurons in the hypothalamic paraventricular nucleus. Endocrinology 139:3262-3270. 
Legradi G, Lechan RM (1999) Agouti-related protein containing nerve terminals innervate thyrotropin-releasing hormone neurons in the hypothalamic paraventricular nucleus. Endocrinology 140:3643-3652.

Legradi G, Emerson CH, Ahima RS, Flier JS, Lechan RM (1997a) Leptin prevents fasting-induced suppression of prothyrotropin-releasing hormone messenger ribonucleic acid in neurons of the hypothalamic paraventricular nucleus. Endocrinology 138:2569-2576.

Legradi G, Hannibal J, Lechan RM (1997b) Association between pituitary adenylate cyclase-activating polypeptide and thyrotropin-releasing hormone in the rat hypothalamus. J Chem Neuroanat 13:265-279.

Legradi G, Emerson CH, Ahima RS, Rand WM, Flier JS, Lechan RM (1998) Arcuate nucleus ablation prevents fasting-induced suppression of Pro-TRH mRNA in the hypothalamic paraventricular nucleus. Neuroendocrinology 68:89-97.

Liposits Z, Merchenthaler I, Reid JJ, Negro-Vilar A (1993) Galaninimmunoreactive axons innervate somatostatin-synthesizing neurons in the anterior periventricular nucleus of the rat. Endocrinology 132:917-923.

Merchenthaler I, Liposits Z (1994) Mapping of thyrotropin-releasing hormone (TRH) neuronal systems of rat forebrain projecting to the median eminence and the OVLT. Immunocytochemistry combined with retrograde labeling at the light and electron microscopic levels. Acta Bio Hung 45:361-374.

Mihaly E, Fekete C, Tatro JB, Liposits Z, Stopa ED, Lechan RM (2000) Hypophysiotropic thyrotropin-releasing hormone-synthesizing neurons in the human hypothalamus are innervated by neuropeptide Y, agoutirelated protein, and $\alpha$-melanocyte-stimulating hormone, J Clin Endocrinol Metab 85:2596-2603.

Murphy B, Nunes CN, Ronan JJ, Harper CM, Beall MJ, Hanaway M Fairhurst AM, Van der Ploeg LH, MacIntyre DE, Mellin TN (1998) Melanocortin mediated inhibition of feeding behavior in rats. Neuropeptides 32:491-497.

Nillni EA, Aird F, Seidah NG, Todd RB, JI Koenig (2000) Prepro$\mathrm{TRH}_{178-199}$ and two novel peptides $\left(\mathrm{pFQ}_{7}\right.$ and $\left.\mathrm{pSE}_{14}\right)$ derived from its processing, which are produced in the paraventricular nucleus of the rat hypothalamus, are regulated during suckling. Endocrinology, in press.

Nishiyama T, Kawano H, Tsuruo Y, Maegawa M, Hisano S, Adachi T, Daikoku S, Suzuki M (1985) Hypothalamic thyrotropin-releasing hormone (TRH)-containing neurons involved in the hypothalamichypophysial-thyroid axis. Light microscopic immunohistochemistry. Brain Res 345:205-218.

Peters A, Palay SL, deF Webster H (1991) The fine structure of the nervous system. Neurons and their supporting cells, Ed 3. New York: Oxford UP.

Petersen SL, McCrone S (1994) Characterization of the receptor complement of individual neurons using dual-label in situ hybridization histochemistry. In: In situ hybridization in neurobiology. Advances in methodology (Eberwine JH, Valentino KL, Barchas JO, eds), pp. 78-94. New York: Oxford UP.
Renaud LP (1981) A neurophysiological approach to the identification, connections and pharmacology of the hypothalamic tuberoinfundibular system. Neuroendocrinology 33:186-191.

Rondeel JM, Heide R, de Greef WJ, van Toor H, van Haasteren GA, Klootwijk W, Visser TJ (1992) Effect of starvation and subsequent refeeding on thyroid function and release of hypothalamic thyrotropinreleasing hormone. Neuroendocrinology 56:348-353.

Rossi M, Kim MS, Morgan DG, Small CJ, Edwards CM, Sunter D, Abusnana S, Goldstone AP, Russell SH, Stanley SA, Smith DM, Yagaloff K, Ghatei MA, Bloom SR (1998) A C-terminal fragment of Agoutirelated protein increases feeding and antagonizes the effect of alphamelanocyte stimulating hormone in vivo. Endocrinology 139:4428-4431.

Samuels MH, McDaniel PA (1997) Thyrotropin levels during hydrocortisone infusions that mimic fasting-induced cortisol elevations: a clinical research center study. J Clin Endocrinol Metab 82:3700-3704.

Sawchenko PE, Swanson LW (1983) The organization of forebrain afferents to the paraventricular and supraoptic nuclei of the rat. J Comp Neurol 218:121-144.

Segerson TP, Kauer J, Wolfe HC, Mobtaker H, Wu P, Jackson IM, Lechan RM (1987) Thyroid hormone regulates TRH biosynthesis in the paraventricular nucleus of the rat hypothalamus. Science 238:78-80.

Swanson LW, Kuypers HGJM (1980) The paraventricular nucleus of the hypothalamus: cytoarchitectonic subdivisions and organization of projections to the pituitary, dorsal vagal complex, and spinal cord as demonstrated by retrograde fluorescence double-labeling methods. J Comp Neurol 194:555-570.

Swanson LW, Sawchenko PE (1983) Hypothalamic integration: organization of the paraventricular and supraoptic nuclei. Annu Rev Neurosci 6:269-324.

Thim L, Kristensen P, Larsen PJ, Wulff BS (1998) CART, a new anorectic peptide. Int J Biochem Cell Biol 30:1281-1284.

Toni R, Lechan RM (1993) Neuroendocrine regulation of thyrotropinreleasing hormone (TRH) in the tuberoinf undibular system. J Endocrinol Invest 16:715-753.

van Haasteren GA, Linkels E, Klootwijk W, van Toor H, Rondeel JM, Themmen AP, de Jong FH, Valentijn K, Vaudry H, Bauer K, Visser TJ, de Greef WJ (1995) Starvation-induced changes in the hypothalamic content of prothyrotrophin-releasing hormone (pro-TRH) mRNA and the hypothalamic release of pro-TRH-derived peptides: role of the adrenal gland. J Endocrinol 145:143-153.

Vrang N, Larsen PJ, Clausen JT, Kristensen P (1999) Neurochemical characterization of hypothalamic cocaine- amphetamine-regulated transcript neurons. J Neurosci 19:RC5 (1-8).

Vrang N, Larsen PJ, Kristensen P, Tang-Christensen M (2000) Central administration of cocaine-amphetamine-regulated transcript activates hypothalamic neuroendocrine neurons in the rat. Endocrinology 141: 794-801. 